\title{
Analysis of Factors Affecting Poverty in West Nusa Tenggara Province, Indonesia
}

\author{
Supriaman $^{1}$, Firmansyah $^{1}$, Edy Yusuf Agung Gunanto ${ }^{1}$ \\ ${ }^{1}$ Department of Economics, Universitas Diponegoro
}

\begin{abstract}
Poverty is a fundamental and multidimensional problem in economic development, especially in developing countries such as Indonesia and underdeveloped region such as Nusa Tenggara Barat province. The percentage of poor people in Nusa Tenggara Barat is relatively higher compared to the percentage of poor people in national level. This study aims to analyze the factors which influence the poverty level in Nusa Tenggara Barat. By employing a panel data regression of 10 Regencies/Cities along 2010-2015, the study finds that the work force skill, investment and income per capita have significant effect to poverty level. The coefficient of work force skill has the highest impact to the level of poverty, which means that that variable is a major factor in reducing poverty in 10 Regencies/Cities of West Nusa Tenggara Province. Based on the results, the study recommends the policy that promote poverty alleviation need to be strengthened by communities and governments.
\end{abstract}

Keywords: poverty; income per capita; work force skill; investment

\section{Introduction}

The problem of poverty in West Nusa Tenggara Province, namely the high percentage of poverty in West Nusa Tenggara Province compared with the percentage of national poverty (see data on poverty from the Central Bureau of Statistics West Nusa Tenggara in Figure 1).

Figure 1. Comparison of the Development of the Poverty Level Percentage of West Nusa Tenggara Province and National 2010-2015

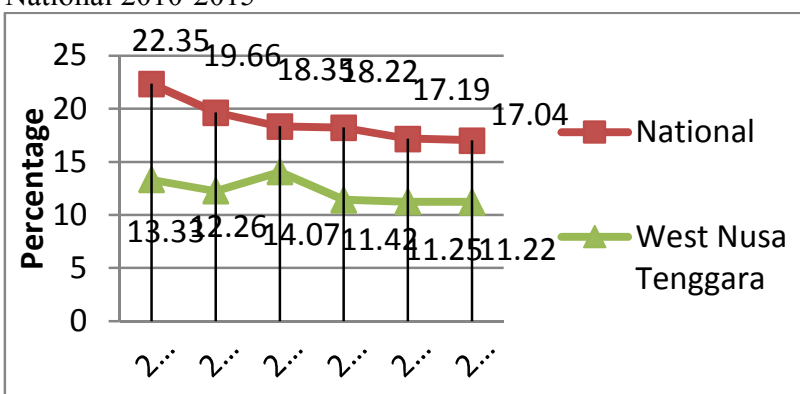

Figure 1

It can be concluded that the population of West Nusa Tenggara Province on average still below the poverty line and is a fact that makes we are concerned because it seems that poverty is still emerging and is part of development, whereas development is aimed at eradicating poverty and not running together, therefore poverty is a shared responsibility, especially for the government as a buffer to the process of improving people's lives in a government to immediately find a way out as an effort to alleviate poverty.
The poverty conditions that occur in West Nusa Tenggara will be exacerbated by environmental degradation in NTB, if poverty continues then it will have an impact on the development of the mindset of the poor who tend to see what environment there is. Their knowledge of disaster mitigation such as floods that often occur in NTB is very little. This limited knowledge will lead to severe environmental damage.

The high level of poverty in a country depends on two main factors, namely; (1) average national income level, and (2) the narrow width of income distribution gap. As high as any national per capita income level achieved by a State, as long as the income distribution is uneven, then the poverty rate in that country will inevitably remain severe, and vice versa, no matter what the income distribution of a country. if the national income level is low, then poverty will also be widespread [1]. Population growth and labor are traditionally considered a positive factor and stimulate economic growth. A larger number of workers means increasing the breadth of the domestic market. Basically the population can be divided into two groups: the population belonging to the labor force group and not the labor force. Increasing population will increase the number of labor and the addition allows an area to increase production.

The study by Maleček et al., said the number of inhabitants in the work force group that is working has an effect on poverty and social welfare, absorbed labor has a significant effect and has a positive relationship to the welfare of society and negatively affect the level of poverty, the amount and productivity of labor impact

\footnotetext{
Corresponding author: firmansyah@live.undip.ac.id
} 
in determining wage levels so as to increase income [2]. The effect of economic growth (GDP) on the poverty level directly is very small but the relationship is negative and significant. Government and labor investments have a negative and significant impact on economic growth. In the short run, there is a significant negative relationship between economic growth and poverty. In the long run there is a significant positive relationship between economic growth and poverty.

Based on the above background it can be seen that the level of poverty is influenced by the factors of labor, the level of investment, the level of education and economic growth. It is certainly on the way have different impact / influence, because related to space and time are different. In order to accommodate the dynamics of poverty between regions and time in the Regency / City in West Nusa Tenggara Province, the research method is done by using regression panel data. The model chosen in explaining poverty is fixed effect dummy individual model. This is because the author wants to see the difference between intercepts and constants every time. Studies of poverty in the region, especially the province of West Nusa Tenggara are still very rare. So far, studies are still observational. Therefore, the researcher wanted to raise the title of this research with the title "Poverty Rate Analysis in West Nusa Tenggara Province Approach Panel Data Regression Data at Regency / City Year 2010-2015".

Based on the results of empirical studies show many factors that affect the level of poverty, one of them labor. The workforce in view has an influence because it describes the economic activity in an area. In addition from the other side of the investment. Investment is one of the factors that can encourage the improvement of people's welfare and reduce poverty level, while the level of education becomes a very important factor to be improved so that the level of population productivity affects the income level and the impact of the decreasing of poverty level.

Based on the above problem formulation, the problems that can be stated in this research is, how is the influence of skilled work force skill, investment and income per capita to poverty in West Nusa Tenggara Province? The purpose of writing is to identify and analyze the effect of per capita income, the skill of the workforce and investment, to poverty in the province of West Nusa Tenggara.

\section{Methodology}

The type of data used in this study is secondary data. Secondary data is data obtained and stored by others who are usually historical data. Secondary data in this research is panel data with observation time range from 2010-2015 or 6 years. Sources of secondary data used in this study were obtained from several agencies / government agencies such as; National Bureau of Statistics (BPS), Central Bureau of Statistics (BPS) of West Nusa Tenggara Province, Office of Manpower and Transmigration West Nusa Tenggara Province, West Nusa Tenggara in Numbers, Regional
Investment Board (BKPM) West Nusa Tenggara Province.

The analysis method used in this research is panel data regression analysis. Panel data analysis is a method that explains the combination of time-series data with cross-section data. The regression model estimation approach used in this research is fixed effect model fixed effect model (FEM) approach. The fixed effect approach assumes the coefficient (slope) of the independent variable is not different for each individual or inter-time. this technique estimates panel data by using dummy variables to see the difference of intercept. Using the poverty-growth model suggested by Ravallion, adopted from the model used by Adonsoua and Sylwester [3]. His research has used this model to investigate the problem of poverty.

The mathematical equation is as follows:

$$
\begin{gathered}
\text { Povertyit }=\beta \_0+\beta \_(1) \mathrm{WFS} \_ \text {it }+\beta \_2 \mathrm{INV} \_ \text {it } \\
+\beta \_3 \mathrm{GDP} \text { it }+\varepsilon \_ \text {it } \ldots . . .(1)
\end{gathered}
$$

Where Povertyit is Poverty, AKit is the skill of INV_it's workforce is investment, PDRBit is, $\beta \_0$ is constant, $\beta \_1 \beta \_2 \beta \_3$ is Slope Coefficient, $\varepsilon$ it is error term, it is cross section-time series (panel data).

\section{Discussion}

Basically there are many theories and approaches in understanding poverty. In simplification, for the purposes of this study there is a paradigm or basic theory of poverty, namely individualistic teories of poverty, paradigm or theory, view poverty as an individual problem, this theory then becomes the basis for analyzing poverty.

Neoliberal poverty theory sees poverty as an individual problem caused by the weakness, failure, and lack of the individual. People get poor due to the combination of several reasons ie. they lack intelligence. competence. and ability. They are not experienced enough. skilled and educated, they lack ambition, determination and persistence, they have a bad thing in attitude. and their values make bad choices and engage in self-destructive behavior, they are unable or unwilling to exert the necessary effort or take advantage of the opportunities available to them.

Proponents of individual theory or often referred to as Neoliberal paradigms such as Spicker, said that poverty is an individual issue caused by individual weaknesses and choices [4]. Poverty will be lost if market forces are exploited as much as possible and economic growth is at the highest level. Therefore, poverty reduction strategies must be residual, "temporary", and involve only the family. self-help groups or religious institutions. Meanwhile, the state only acts as a controller and can intervene only if the institutions are unable to perform their duties.

The underlying logic of cultural / cultural theory of poverty resembles logic in biogenetic theory. If the biogenetic theory of poverty is more determined by the cognitive abilities of the poor, the theory of poverty culture is more due to the lack of motivation to achieve something. Cultural theory states that the poor have 
one different thought in terms of values, aspirations, beliefs, dispositions, and psychological characteristics. Characteristic of the culture and lifestyle of the poor is a unique culture of poverty. often understood as an anti-thesis of a culture that was developing at that time.

Human capital theory says a person becomes poor because of the bracket of education. skills. and work experience. This theory concludes one's productivity will determine the amount of income. Workers with good skills and skills will get a good job, while less competent workers, if they can find a job, will be channeled into the economy with low wages. The conclusion of this theory is that those who are rich in human resources contribute more to economic output, growth, and profitability. and they deserve a higher wage.

One of the benchmarks of economic development success needed for macroeconomic evaluation and planning. usually seen from the number and percentage of poverty levels. The mean value of poverty in the District of West Nusa Tenggara (mean) is $18.49 \%$, median of $17.05 \%$, and standard deviation $7.17 \%$, the lowest value (minimum) and the highest value of poverty (maximum) of $43.14 \%$.

Based on the estimation result in equation 1 it is known that income variable per capita, labor force productivity and investment significantly influence poverty level in Regency / Municipality of West Nusa Tenggara Province.

Table 1. the result of the estimation of the regression variables that influence poverty levels with a fixed effects model approach

\begin{tabular}{lrrr}
\hline \multicolumn{1}{c}{ Variable } & Coefficient & t-statistic & $\begin{array}{l}\text { t- } \\
\text { table }\end{array}$ \\
\hline $\begin{array}{l}\text { LOG Constanta } \\
\text { (POV) }\end{array}$ & 2,96289 & 73,28 & \\
WFS & $-9,19$ & $-176^{* *}$ & \\
INV & $-1,69$ & $-291^{* *}$ & 163 \\
GDP per capita & $-2,14$ & $-186^{* *}$ & \\
R-squared & 0,946722 & & \\
F-statistic & 6,959687 & & \\
Prob(F-statistic) & 0,000000 & & \\
Durbin-Watson stat & 1,080063 & & \\
\hline
\end{tabular}

Source: Output the results of Eviews 9. 2017.

** A description of significant t.table $<$ t.statistics at level $>0.05$

\section{Coefficient of Determination (R2)}

The coefficient of determination is used to see and measure how big the model capability in explaining the variation of the dependent variable. If the value of R2 is less than $50 \%$ then it can be said the ability of independent variables in explaining the variation of the dependent variable is very limited, vice versa. Return on equation 3.1 which shows the value of $\mathrm{R} 2$ for this research model that is equal to $94 \%$. This means that per capita income variables, workforce skills and poverty investment in West Nusa Tenggara province account for $94 \%$ while $16 \%$ are explained by other variables outside the model.

\section{Partial Significance Test (Test Statistic t)}

The working skill variable of the labor force shows the direction of negative and statistically significant effect on poverty, at the level of 5\% $\alpha$-pha significance. This means that any increase in the skill of the workforce that is working will reduce the poverty level in the Regency / City of West Nusa Tenggara Province. Based on the coefficient value of 9,19 and the value of $t$ table $<\mathrm{t}$ statistics $(1,67<1,76)$, that can be interpreted every skill improvement workforce of $1 \%$ will reduce the level of poverty in West Nusa Tenggara Province 9,19\%. The influence of skilled labor force skills factor has a great effect on the decreasing of poverty level in West Nusa Tenggara Province based on the result of regression variable estimate in Table 1.

The investment variable shows the direction of the negative and statistically significant effect on poverty at the $5 \%$ significance level of alpha. This means that any increase in investment will reduce poverty in the Regency / City of West Nusa Tenggara Province. Based on the coefficient value of 1,69 and $t$ table $<\mathrm{t}$ statistics $(1,67<1,76)$, that an increase of $1 \%$ investment will reduce the poverty rate in the Regency / City of West Nusa Tenggara Province by 1,69\%. The influence of investment factor on poverty is very small compared to the influence of the skill factor of the labor force. This means that the contribution of investment factors in reducing poverty has a very low effect, so that the investment factor can not be rely on implementing poverty alleviation policies.

The per capita income variable shows negative and statistically significant direction of poverty at the $5 \%$ significance level of $\alpha$ lpha. It means that every $1 \%$ increase in per capita income will decrease poverty level in West Nusa Tenggara Province. Based on the coefficient value of $2,14 \%$ and the value of $t$ table $<\mathrm{t}$ statistics $(1,67>1,86)$, that per capita income variable has no effect on poverty in the Regency / City of West Nusa Tenggara Province of 2,14\%. Based on regression estimation results. The income factor per capita has a significant effect on poverty reduction in the Regency / Municipality of West Nusa Tenggara Province, even though its influence is relatively low compared to the variable skill of the workforce at work.

\section{Simultaneous Significance Test (Test Statistic F)}

Based on the equation in obtaining the F-count value of 65.59 is greater than the F-table value of 2,77 and the probability value F-count 0,0000 is smaller than $0,05(\alpha=5 \%)$. Therefore, it can be concluded that H1 expressing free variables such as per capita income, labor force skill, investment, together have a significant influence in reducing poverty level in West 
Nusa Tenggara Province districts in 2010-2015, proven.

\section{Conclusion}

Based on the results of the analysis done in equation 1 , then it can be concluded as follows:

1. The result of determination coefficient test (R2) In equation 1, per capita income (GDP per capita), workforce skills (WFS) and investment (INV) skills on poverty in West Nusa Tenggara Province 2010-2015 show relatively high ie $94 \%$ of the value means that the independent variable is relatively well explained poverty variables and more than $16 \%$ is explained by other variables.

2. Based on the calculation with the F test, in equation 1 , it can be concluded that there is an influence between per capita income variable, labor skills and investment, to poverty in West Nusa Tenggara Province in 2010-2015 with a real level of 5\%, and the highest factor in affecting poverty is seen from the coefficient value in equation 1 , that the skills factor of work is one of the bigger factors in influencing poverty in West Nusa Tenggara Province based on the value of statistical coefficient.

\section{References}

1. M. P. Todaroand Smith, C. Stephen, Economic Development (1 $1^{\text {th }}$ eds.), (2011).

2. P. Malečeka, K. Čermákováa, In-work Poverty in the Czech Republic: Identification of the Most Vulnerable Groups (2015).

3. Adonsoua, Sylwesterb, Financial development and poverty reduction in developing countries: New evidence from banks and microfinance institutions (International journal ScienceDirect Economics and Finance 82-90, 2016).

4. P. Spicker, Social Policy: Themes and Approaches (1995).

5. F.S. de Lima, F. A. Barreto, E. Marinho, Impacto do crescimento econômico e da concentrac, ão de renda sobre o nível de pobreza dos estados brasileiros. ENCONTRO Regional De Economia, 7, Fortaleza. Anais, Fortaleza (2003).

6. Hirschman, The Strategy of Economic Development (Yale University Press, New Haven 1958). 